\title{
PENGARUH WAKTU PEMBAHARUAN SADAPAN POHON PINUS (Pinus merkusii) PADA UMUR BERBEDA TERHADAP PRODUKTIVITAS GETAH
}

\author{
Effect of Update Time Tapping Pine Trees (Pinus merkusii) in Different Ages \\ Pine Sap Productivity
}

\author{
Muhamad Ramdan" ${ }^{1)}$, Raizal Fahmi Solihat ${ }^{2)}$, Asep Purwanto ${ }^{3)}$ \\ 1) Perum Perhutani Divisi Regional Jawa Barat-Banten, Jl. Soekarno Hatta No \\ 628, Cimenereng, Kec. Gedebage, Kota Bandung; \\ muhammadramdan1234@gmail.com \\ 2) Fakultas Kehutanan Universitas Winaya Mukti; raizalfahmi@unwim.ac.id \\ 3)Fakultas Kehutanan Universitas Winaya Mukti; aseppurwanto870@gmail.com
}

\section{Diterima 8 September 2020/Disetujui 1 Oktober 2020}

\begin{abstract}
Pine sap exploitation is growing because demand for pine sap in Indonesia and the world is increasing. Pine sap productivity is influenced by several factors including tapping, tree species, diameter, and age of stands. In the tapping method, one of them is the renewal time of tapping with the quarre system which is supposed to save the tapping area and get the maximum sap. This paper studies the effect of the renewal of the pine tree tapping at different ages on the productivity of the sap. The proposed method is a survey with a purposive sample determination with 3 different treatments, namely treatment $A$ of the 3-day quarre renewal, treatment $B$ of the 5-day quarre renewal, and treatment of the renewal of the 7-day quarre by administering stimulants. Performed at different age classes IV, VI, and VIII. Field observational data is then processed using a factorial Completely Randomized Plan analysis with two factors. The results showed that the renewal of quarre had a significant effect on the average productivity of pine tree sap at $95 \%$ confidence intervals $(\alpha=0.05)$. The highest average productivity on treatment $B$ renewal of 5 days quarre was 12.17 grams /quarre/day at age classes VI and the lowest average productivity was at treatment $C$ of renewal of 7 days with 4.61 grams /quarre/day at age classes IV.

Keyword : Update tapping, Different ages, Pine sap
\end{abstract}

\section{PENDAHULUAN}

Salah satu HHBK (Hasil Hutan Bukan Kayu) yang hingga saat ini masih dimanfaatkan yaitu getah pinus yang berasal dari jenis Pinus merkusii karena 
dianggap memiliki banyak manfaat. Pinus merkusii merupakan tanaman asli Indonesia yang menghasilkan getah dan jika setelah diolah akan menjadi gondorukem dan terpentin. Marjati (1994) menambahkan bahwa seiring kemajuan teknologi mengakibatkan gondorukem tidak lagi sekedar untuk keperluan industri batik tetapi juga merupakan bahan baku bagi industri lainnya, seperti adesif, kertas, tinta cetak dan permen karet. Sastrohamidjojo (2004) juga menambahkan bahwa terpentin digunakan juga sebagai pelarut minyak organik dan sebagai pengencer cat dan pengkilap, perekat serta pelarut lilin.

Penyadapan getah pinus dapat dilakukan dengan berbagai metode, yaitu metode square dan bor. Teknik penyadapan ini biasanya akan berpengaruh terhadap hasil dari getah itu sendiri atau yang dikenal dengan istilah produktivitas getah. Produksi getah perlu diketahui untuk memperoleh informasi mengenai kelas umur dan individu pohon yang bergetah banyak. Informasi ini sangat penting untuk keperluan pengelolaan produksi getah pinus di masa yang akan datang. Pengusahaan getah pinus juga saat ini semakin berkembang, sehingga permintaan getah pinus di Indonesia maupun dunia semakin meningkat. Oleh karena itu, perlu dilakukan upaya untuk meningkatkan produktivitas getah pinus di Indonesia.

Penelitian tentang faktor-faktor yang dapat mempengaruhi produktivitas getah ini telah banyak dilakukan, seperti Soekarno et. al. (2011) yang melakukan penelitian terhadap produksi getah pinus dari pengaruh perbedaan kelas umur, Sudrajat et.al. (2002) dari pengaruh diameter pohon, umur dan kadar stimulant, dan Samosir et al (2015) dilihat dari ketinggian tempat dan konsentrasi stimulansia asam cuka (C2H4O2). Oleh karena itu, diperlukan penelitian serupa dari hal yang berbeda, yaitu pengaruh dari pembaharuan sadapan pada umur berbeda, sehingga diperoleh informasi yang tepat dalam proses penyadapan getah pinus tersebut. Pada saat ini di perum perhutani pelaksanaan pembaharuan bidang sadapan pinus dilakukan setiap 3 (tiga) hari, pada penelitian ini diujikan dengan waktu pembaharuan bidang sadap atau koakan dengan waktu 5 (lima) dan 7 (tujuh) hari. Informasi ini sangat penting untuk keperluan pengelolaan produksi getah pinus di masa yang akan datang.

\section{METODE PENELITIAN}

Penelitian dilakukan di perum perhutani KPH Purwakarta dengan objek yang diteliti yaitu tegakan pinus (Pinus merkusii) yang sudah di sadap (Sadap Lanjut) Kelas Umur IV, Kelas Umur VI dan Kelas Umur VIII dengan kelas kesuburan tanah yang sama (Bonita 4). Data hasil penyadapan getah pinus melalui 
pengambilan getah pinus dengan melakukan kegiatan penimbangan getah pinus pada pohon sampel di tingkat kelas umur yang berbeda, dengan jumlah pembaharuan yang berbeda. Penyadapan getah dengan menggunakan sistem koakan/quarre hasilnya yaitu berupa data hasil penyadapan getah pinus yang disadap pada 90 pohon dengan metode quarre selama 25 hari. Pohon contoh di bagi kedalam tiga (3) perlakuan yaitu :

a. Perlakuan A : Pembaharuan quarre 3 hari dengan pemberian stimulansia sebanyak 10 Pohon setiap Kelas Umur ( 10 x 3 Kelas Umur $=30$ pohon $)$

b. Perlakuan B : Pembaharuan quarre 5 hari dengan pemberian stimulansia sebanyak 10 Pohon setiap Kelas Umur ( 10 x 3 Kelas Umur $=30$ pohon $)$

c. Perlakuan $\mathrm{C}$ : Pembaharuan quarre 7 hari dengan pemberian stimulansia sebanyak 10 Pohon setiap Kelas Umur ( 10 x 3 Kelas Umur $=30$ pohon $)$

Penyemprotan stimulansia Socepas pada pembaharuan berdasarkan perlakuan masing-masing dengan dosis $2 \mathrm{cc}$ per quarre dengan jarak penyemprotan $20 \mathrm{~cm}$. Total sadapan yang diperoleh selama 25 hari akan di perhitungkan dalam satuan gram/quarre/hari. Pohon yang diuji mempunyai keliling batang antara 85 $\mathrm{cm}-120 \mathrm{~cm}$ (Diameter $28-38 \mathrm{~cm}$ ).

\section{Penentuan Sampel Pohon}

Penentuan sampel pohon dilakukan dengan mengambil sampel pohon sebanyak 10 pohon pada setiap Kelas Umur. Kriteria pohon uji yang dimaksud yaitu pohon yang berada di KU IV, KU VI dan KU VIII, pohon yang mendapatkan perlakuan yang sama, pohon yang diameter batangnya pada kisaran yang sudah ditentukan.dan terakhir kriteria pohon uji yaitu sehat, tidak cacat, bertajuk lebat dan tidak terserang oleh hama dan penyakit. Pengambilan sempel pohon menggunakan proposive sempling. Untuk menghitung jumlah pohon sampel dengan menggunakan rumus :

$$
\mathrm{n}=10 \mathrm{x} \text { jumlah perlakuan }
$$

Keterangan :

$$
\begin{aligned}
& \text { n } \quad \text { Jumlah pohon sampel dalam tiap Kelas Umur } \\
& 10 \quad \text { : Jumlah Pohon Sampel }
\end{aligned}
$$

\section{Analisis Data}

Dapat diketahui perbedaan produktivitas getah pinus merkusii pada Kelas Umur berbeda dengan perlakuan pembaharuan yang berbeda. Data pengamatan dilapangan kemudian diolah menggunakan analisa Rencana Acak Lengkap (RAL) faktorial dengan dua faktor. Faktor pertama adalah Perlakuan pembaharuan yang 
berbeda dibagi menjadi 3 karakter diantaranya 3 hari sekali, 5 hari sekali, dan 7 hari sekali, Faktor yang kedua adalah. Kelas Umur yang berbeda terdiri dari 3 tingkatan kelas umur yaitu, KU IV, KU VI dan KU VIII perlakuan dalam penelitian ini adalah hasil kombinasi antara faktor jumlah pembaharuan yang berbeda dengan kelas umur. Dengan demikian dalam penelitian ini terdapat $3 \times 3$ x 10 kombinasi atau 90 kombinasi.

\section{HASIL DAN PEMBAHASAN}

\section{Produktivitas Getah}

Produktivitas getah pinus dari hasil penelitian yang dilakukan selama 25 hari sehingga pada periode pembaharuan quarre 3 hari dilakukan 6 kali panen, untuk periode pembaharuan quarre 5 hari dilakukan 4 kali panen, dan untuk pembaharuan quarre 7 hari dilakukan 3 kali panen. Meskipun dalam jumlah pengulangan panennya berbeda-beda akan tetapi satuan yang menjadi acuan dalam penghitungannya adalah gram/hari/quarre. Berikut ini data rata-rata produktivitas getah pohon pinus pada Kelas Umur (KU) IV, Kelas Umur (KU) VI, dan Kelas Umur (KU) VIII pada Gambar 1.

\section{RATA-RATA PRODUKTIVITAS GETAH PINUS}

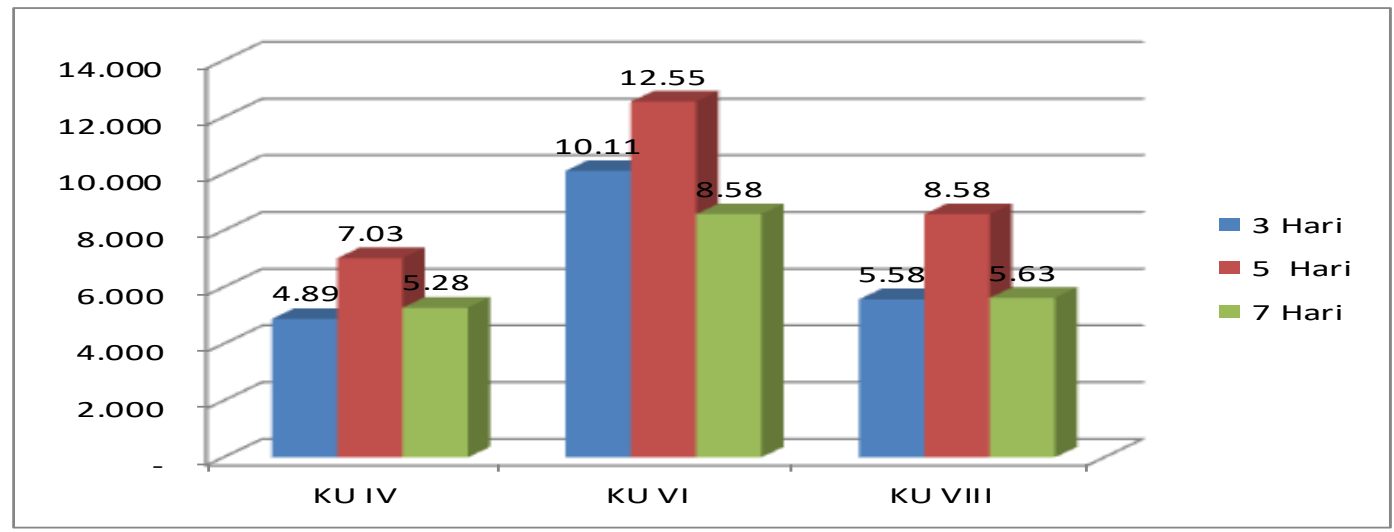

Gambar 1. Rata-rata Produktivitas Getah Pohon Pinus

Gambar 1 menjelaskan bahwa produktivitas getah pada setiap umur berbeda-beda sesuai dengan periode pembaharuan. Pada Gambar 1 terlihat bahwa pada setiap kelas umur (KU) menunjukan bahwa rata-rata produktivitas tinggi apabila pembaharuan quarre dilakukan 5 hari dibanding dengan pembaharuan 3 hari dan 7 hari, dan untuk produktivitas tertinggi terdapat pada kelas umur (KU) VI dengan periode lama pembaharuan quarre 5 (lima) hari. Sedangkan untuk pembaharuan periode 3 dan 7 hari cenderung sama pada setiap umur dan produktivitas getahnya. Padahal jika menurut Sudradjat et al. (2002) menunjukkan bahwa semakin tinggi umur pohon, getah yang dihasilkan cenderung lebih sedikit. Namun pada penelitian ini kelas umur tidak berpengaruh 
terhadap produktivitas, tetapi pembaharuan sadapan yang berpengaruh terhadap produktivitas getah. Untuk mengetahui pengaruh berbagai perlakuan periode lama pembaharuan terhadap produktivitas penyadapan getah pinus maka dilakukan pengolahan statistik pada data hasil pengukuran.

Hasil dari analisis data dengan Analisis Sidik Ragam untuk Rancangan Acak Lengkap, yaitu Waktu sadapan, pengaruh waktu pembaharuan sadapan terhadap produktivitas getah di dalam model. Apabila Signifikansi (Sig.) $<0,05$ (Alfa) = Signifikan. Hasil diatas 0,021 berarti waktu pembaharuan sadapan berpengaruh signifikan. Kelas umur, pengaruh kelas umur terhadap produktivitas getah didalam model. Apabila Signifikansi (Sig.) $<0,05$ (Alfa) $=$ Signifikan. Hasil diatas 0,000 berarti kelas umur berpengaruh sangat signifikan. Dari hasil analisa di atas dalam uji Anova bahwa lama pembaharuan dan kelas umur berpengaruh secara signifikan. Untuk memperkuat uji Anova maka dilakukan uji lanjutan. Uji lanjut yang dilakukan untuk uji lanjut yaitu uji Duncan.

\section{a. Waktu Pembaharuan sadapan}

Pelaksanaan sadapan di Perum Perhutani pada umumnya menggunakan motode quarre atau koakan, pembaharuan quarre (luka sadapan) dilakukan setiap 3 hari sekali diatas luka yang telah ada dengan panjang quarre $5 \mathrm{~mm}$ dengan kedalaman quarre $1-2 \mathrm{~cm}$. Dengan demikian luka sadapan yang ditimbulkan oleh kegiatan sadapan dalam 1 (satu) bulannya yaitu 30 hari dilakuakn pelukaan setiap 3 hari sekali dengan ketebalan luka $5 \mathrm{~mm}$ sehingga dalam 1 bulan terdapat luka quarre $5 \mathrm{~cm}$ (maksimum) dalam 1 (satu) tahun terdapat 12 bulan x $5 \mathrm{~cm}=60$ $\mathrm{cm}$ dan dalam 3 tahun bisa mencapaitinggi $180 \mathrm{~cm}$. Seiring permintaan produksi getah yang meningkat, upaya peningkatan produksi getah secara teknis di lapangan dilakukan dengan penggunaan stimulan dalam kegiatan penyadapan pinus.

Stimulan merupakan bahan yang bersifat asam yang dapat menghasilkan suatu reaksi, keadaan, ataupun proses yang bersifat rangsangan sehingga stimulan dikenal juga sebagai zat perangsang. "Pada penyadapan pinus, penambahan substansi asam dimaksudkan untuk mengurangi pembekuan atau pengeringan getah yang keluar akibat perlukaan batang" (Rodrigues et. al (2007); Penggunaan stimulan dalam penyadapan pinus pada awalnya menggunakan bahan dasar asam sulfat $\left(\mathrm{H}^{2} \mathrm{SO}^{4}\right)$ dengan konsentrasi $40 \%$ atau 60\% (Sutjipto, 1975) dan hingga sekarang stimulan berbahan dasar asam sulfat masih digunakan di wilayah Perum Perhutani namun dalam konsentrasi yang lebih rendah.

Getah pinus yang dihasilkan dari penggunaan stimulan berbahan dasar $\mathrm{H}^{2} \mathrm{SO}^{4}(20 \%-24 \%): \mathrm{HNO}^{3}(0-1 \%): \mathrm{HCl}(0,5-1 \%)$ dapat menaikkan hasil produksi getah sebesar 56-111\% (Perum Perhutani, 2010). Penggunaan stimulan 
berbahan dasar asam kuat dapat meningkatkan produksi getah pinus per pengunduhan. Dari hasil penelitian yang dilakukan didapatkan produktivitas getah yang tinggi terdapat pada pembaharuan 5 hari sekali diduga dalam proses metabolisme pohon pinus pada pembaharuan quarre 5 hari pohon pinus masih mengeluarkan getah akibat adanya rangsangan zat perangsang berupa stimulansia socepas yang berbahan dasar asam sulfat yang bersifat panas sehingga penyembuhan pada luka pada pohon pinus lambat dan getah terus mengalir. Hal ini ditunjukan pada hasil uji lanjut Duncan (Tabel 1).

Tabel 1. Hasil Uji Lanjutan Duncan Hari atau Lama Pembaharuan

\begin{tabular}{cc}
\hline $\begin{array}{c}\text { Waktu } \\
\text { Pembaharuan }\end{array}$ & $\begin{array}{c}\text { Rata-rata Produktivitas } \\
\text { (gram/quarre/hari) }\end{array}$ \\
\hline 3 Hari & $6,86^{\mathrm{b}}$ \\
\hline 5 Hari & $9,38^{\mathrm{a}}$ \\
\hline 7 Hari & $6,43^{\mathrm{b}}$ \\
\hline
\end{tabular}

Hasil uji lanjutan di atas diperoleh hasil bahwa pada pembaharuan quarre dengan perode pembaharuan 5 hari menghasilkan produksi getah yang tinggi yaitu 9,38 gram. Data diatas menunjukan hasil produksi gram yang berbeda-beda akan tetapi untuk pembaharuan quarre dengan periode 3 dan 7 hari perbedaannya tidak jauh berbeda. Maka untuk hasil produksi yang tertinggi adalah pembaharuan quarre yang dilaksanakan 5 hari.

\section{b. Kelas Umur (KU)}

Penyadapan getah pinus oleh Perum Perhutani dilakukan pada umur 11 (sebelas) tahun (kelas umur III) sampai umur 34 tahun (kelas umur VII). Selanjutnya pohon pinus akan ditebang dan dimanfaatkan kayunya. Dari hasil penelitian yang dilakukan di RPH Cijambe BKPH Tambakan KPH Purwakarta di dapat hasil bahwa pada Kelas Umur (KU) IV menghasilkan produksi getah sebesar 5,73 gram/quarre/hari, sedangkan Kelas Umur (KU) VI menghasilkan produksi getah sebesar 10,34 gram/quarre/hari, dan Kelas Umur (KU) VIII menghasilkan produksi getah sebesar 6,60 gram/quarre/hari.

Penelitian penyadapan getah pinus berdasarkan perbedaan kelas umur telah dilaksanakan di RPH Oro-oro Ombo, BKPH Pujon, KPH Malang pada tahun 2012. Hasil penelitian menunjukkan bahwa produksi getah kelas umur III $(36,5$ $\mathrm{g} / 2$ lubang/1 hari) meningkat pada kelas umur IV (62,9 g/2 lubang/1 hari) dan menurun pada kelas umur V (24,61 g/2 lubang/1 hari) dan sedikit meningkat pada kelas umur VI (38,3 g/2 lubang/1 hari) (Sukarno, Hardiyanto \& Marsoem (2012)). 
Dari hasil penelitian diatas dapat melengkapi penelitian yang dilakukan ini bahwa Kelas Umur (KU) berpengaruh nyata terhadap produktivitas getah pinus dimana pada kelas umur III ke kelas umur IV mengalami peningkatan dan mengalami penurunan kembali pada kelas umur $\mathrm{V}$ dan kembali mengalami kenaikan pada kelas umur VI, dan dari penelitian yang telah dilakukan di dapatkan bahwa kelas umur VI merupakan kelas umur produktif dalam menghasilkan produktivitas getah hal tersebut ditunjukan oleh hasil uji lanjut Duncan (Tabel 2).

Tabel 2. Hasil Uji Lanjutan Duncan Kelas Umur

\begin{tabular}{cc}
\hline Kelas Umur & $\begin{array}{c}\text { Rata-rata Produktivitas } \\
\text { (gram/quarre/hari) }\end{array}$ \\
\hline IV & $5,73^{\mathrm{b}}$ \\
\hline VI & $10,34^{\mathrm{a}}$ \\
\hline VIII & $6,60^{\mathrm{b}}$ \\
\hline
\end{tabular}

Hasil uji lanjutan di atas diperoleh hasil bahwa pada Kelas Umur (KU) VI menghasilkan produksi getah yang paling tinggi yaitu 10,34 gram. Data di atas menunjukan kenaikan produksi getah pada awal Kelas Umur (KU) IV ke Kelas Umur (KU) VI yaitu dari produksi 5,73 gram ke Produksi 10,34 gram, sedangkan pada Kelas Umur (KU) VI ke Kelas Umur VIII mengalami penurunan produktisi yaitu dari produksi 10,34 gram ke Produksi 6,60 gram. Sedangkan untuk produktivitas getah tertinggi yaitu berada pada Kelas Umur VI.

Produktivitas getah pohon pinus ( Pinus Merkusii) dapat di pengaruhi oleh faktor-faktor alam yang berkaitan dengan kulitas lahan, diantranya adalah umur, diameter, ketinggian, kerapatan tegakan pohon pinus, kesuburan lahan (bonita), jumlah quarre sadapan, waktu pembaharuan quarre dan faktor Sumber Daya Manusia yang dilihat dari keterampilan penyadap getah pohon pinus.

Perbandingan produksi getah tiap Kelas Umur (KU) dan waktu Pembaharuan quarre tiap perlakuan dapat di lihat pada Gambar 2. Gambar 2 menjelaskan bahwa produktivitas getah pinus tiap Kelas Umur (KU) memiliki hasil produksi yang berbeda-beda akan tetapi dari keseluruhan Kelas Umur yang di teliti memperlihatkan bahwa produksi getah pinus tertinggi berada pada masa periode pembaharuan quarre 5 hari pada Kelas Umur (KU) VI. Menurut Sukarno (2012) penyadapan getah pertama kali (sadap buka) sebaiknya dilakukan pada pada kelas umur III (umur 11-15 tahun) seperti yang dilakukan oleh Perum Perhutani pada pertumbuhan pohon yang normal. Getah yang dihasilkan pohon pinus merkusii digolongkan sebagai oleoresin yang merupakan cairan asam-asam resin dalam terpentin yang menetes keluar apabila saluran resin pada pada kulit 
pohon jenis daun jarum tersayat atau pecah. Saluran getah resin bukan merupakan bagian dari kayu, tetapi berupa rongga yang dikelilingi oleh sel-sel parenkimatis atau sel epitel. Seluruh lapisan yang mengelilingi saluran resin disebut epitellium. Saluran resin adalah suatu saluran yang terdapat pada saluran pohon pinus, maka getah yang mengandung resin akan keluar melaluinya, apabila pohon pinus dilukai.

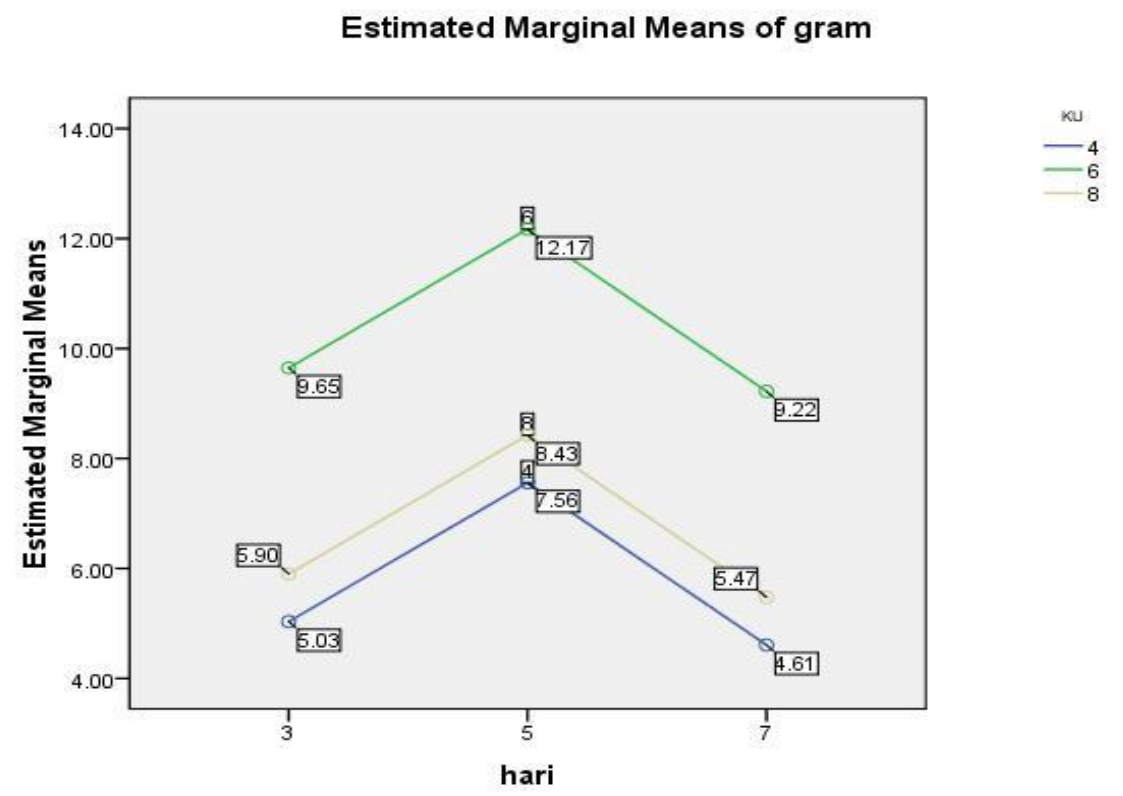

Gambar 2. Rata-rata Produktivitas dilihat dari KU dan Pembaharuan.

\section{SIMPULAN}

Periode pembaharuan dengan menggunakan metode quarre dan perlakuan pembaharuan quarre yang berbeda memberikan pengaruh nyata terhadap produktivitas getah pohon pinus (Pinus merkusii). Produktivitas rata-rata tertinggi pada perlakuan B pembaharuan quarre 5 hari dengan pemberian stimulansia didapat hasil getah sebesar 12,17 gram/quarre/hari pada KU (Kelas Umur) VI dan Produktivitas rata-rata terendah pada perlakuan $\mathrm{C}$ pembaharuan quarre 7 hari dengan pemberian stimulansia didapat hasil getah sebesar 4,61 gram/quarre/hari pada KU (Kelas Umur) IV. Sehingga terpilih waktu pembaharuan quarre terbaik adalah 5 hari dengan pemberian stimulansia pada KU (Kelas Umur) VI. 


\section{DAFTAR PUSTAKA}

Dharmawan, K. (2007). Optimasi Jumlah Pohon Sadapan Bagi Penyadap untuk Meningkatkan Produktivitas Penyadapan Getah Pinus di KPH Kedu Selatan PT. Perhutani Unit I Jawa Tengah. (skripsi). Fakultas Kehutanan Institut Pertanian Bogor, Bogor.

Hillis, W.E . (1987). Heartwood and Tree Exudate. Springer Verlag. Berlin Heidelberg, New York, London.

Kasmudjo. (2011). Hasil Hutan Non Kayu Suatu Pengantar. Yogyakarta: Cakrawala Media.

Mariana. (2008). Teknik Dan Waktu Penyadapan Terhadap Produksi Getah Pinus (Pinus merkusii Jung et de Vries) Di Desa Uwemanje Kecamatan Marawola Kabupaten Donggala. Skripsi. Program Studi Manajemen Hutan Jurusan Kehutanan Fakultas Pertanian, Universitas Tadulako.

Marjati, K., 1994. Industri Non Kayu Menjelang Abad XXI. Duta Rimba IX (169-170):41-47.

Samosir, A., R. Batubara, A. Dalimunte. (2015). Produktivitas Getah Pinus (Pinus Merkusii Jungh Et De Vriese) Berdasarkan Ketinggian Tempat dan Konsentrasi Stimulansia Asam Cuka (C2H4O2). Universitas Sumatera Utara, Medan. Hal 1-7.

Sastrohamidjojo, H. (2004). Kimia Minyak Atsiri. Yogyakarta: Gadjah Mada University Press.

Sudradjat R., D. Setyawan dan S. Sumadiwangsa. (2002). Pengaruh Diameter Pohon, Umur dan Kadar Stimulan terhadap Produktivitas Getah Tusam. Buletin Penelitian Hasil Hutan, 20(2), 143-158.

Sukarno A., Hardiyanto E.B., Marsoemi S.N., Na'iem M. (2012). Pengaruh Perbedaan Kelas Umur terhadap Produktivitas Getah Pinus merkusii Jungh et de Vriese Ras Lahan Jawa melalui Penyadapan Getah Metode Bor (Effect Of Among Age Class Differences On Oleoresin Production Pinus merkusii Jungh et de Vriese Java Land Race Tapping By Drill Method). J-PAL Vol. 3 No. 1, 2012.

Sumardiwangsa, ES. (2000). Pemanfaatan Resin Untuk Meningkatkan Pendapatan Masyarakat Sekitar Hutan. Di dalam : Peningkatan Efisien Pemanfaatan Kayu dan Hasil Hutan Bukan Kayu. Prosiding Lokakarya Penelitian Hasil Hutan: Bogor 7 Desember 2000. Bogor: Pusat penelitian dan Pengembangan Kehutanan Departemen Kehutanan

Syamsu A F. 2009. Desain Chain of Custody (CoC) Lacak Getah Pinus Di KPH Banyuwangi Utara Perum Perhutani Unit II Jawa Timur. (Skripsi). Institut Pertanian bogor, Bogor. 